\title{
気温・地温観測結果からみた飛騨山脈槍・穂高連峰における 山岳永久凍土の分布状況
}

\author{
青山雅史 (財団法人日本地図センター連携研究員)
}

\begin{abstract}
飛騨山脈南部槍・穂高連峰における山岳永久凍土の有無およびその分布状況を明らかにするため，小型自記 温度計を用いて, 気温および地温の観測を抢こなった。気温観測の結果, 槍・穂高連峰主稜線上は不連続永久 凍土带の気温条件下にあることが判明した。 また，地表面温度観測の結果，本山域のカール内に存在する岩石 水河や崖錐斜面上の多数の地点に扔ける晚冬季の積雪底地表面温度（BTS）の值は, それらの地点に永久凍土 が存在する可能性があることを示した. 特に, 大キレットカール内の岩石水河上では, 永久凍土が存在してい る可能性が高いことを示す BTS や年平均地表面温度などの值が複数年にわたって得られた. 地表面が特に粗 大な砂から成る地点では, 冬季の地表面温度の低下が他地点よりも顕著であった。これは, 冬季に粗大砂の上 部が積雪面上に露出し, その露出部が寒冷な外気により冷却され, 礫自体の冷却が進行していくことによりも たらされたものと考えられる.

キーワード：山岳永久凍土, 地表面温度, 冬季積雪底地表面温度 (BTS), 岩塊地, 槍・穂高連峰
\end{abstract}

\section{I はじめに}

山岳永久凍土は気候変化に敏感に応答するため, 山岳水河とともに山岳地域における環境变動の良い 指標となる．近年では，地球温暖化の影響によって 山岳永久凍土の融解が進行していることが報告され ている（たとえば, Haeberli 1992; Haeberli et al. 1993; Harris et al. 2001). したがって, 山岳永久 凍土の分布や形成環境を明らかにすることは，山岳 地域の環境変動や近年の気候変動の検出といった観 点から重要といえよう。そのため, 世界のさまざま な地域に扔いて, 山岳永久凍土の分布に関する研究 がおこなわれている（たとえば, Etzelmüller et al. 2001; Hoelzle et al. 2001; Vonder Mühll et al. 2002).

日本においても山岳永久凍土に関する研究が近年 多くおこなわれるようになり, 山岳永久凍土の存在 が確認されていた富士山（Higuchi and Fujii 1971; 藤井・樋口 1972）や大雪山（福田・木下 1974）の ほかにも, 飛騨山脈北部の立山連峰内蔵助カールに
おいて現存の山岳永久凍土が確認された（福井・岩 田 2000). また, 大雪山では, 永久凍土の分布や形 成環境などに関する詳細な情報が蓄積されており （高橋 ·曾根 1988; Sone 1992； Ishikawa and Hirakawa 2000), 日高山脈ポロシリ岳周辺（石川 ほか 2002), 飛騨山脈南部槍 ·穂高連峰（青山 $2002 b)$ ，赤石山脈北部間ノ岳周辺（Matsuoka and Ikeda 1998; Ishikawa et al. 2003) などにおいて も, 山岳永久凍土が現存する可能性があることが指 摘されている.

さらに，これまでモレーンやプロテーラスランパー トと解釈されてきた中部山岳地域の岩塊堆積地形に は，山岳永久凍土の存在を示す示標地形である岩石 水河が多く含まれていることが指摘されている（青 山 2002a). 北海道, 然別火山群西ヌプカウシヌプ リの岩塊斜面では, 点在的永久凍土の存在とその形 成・維持機構が明らかにされている（澤田・石川 2002; Sawada et al. 2003).

飛騨山脈南部槍・穂高連峰では, 1 年間の地表面 温度の観測結果や岩石水河の形態的特徵および植被 
状況に基づいて，岩石水河内部の永久凍土の有無が 推定されている（青山 2002b）が，観測地点が少な いため，本山域における山岳永久凍土の分布状況を 明らかにするには至っていない。また，山岳地域に おける地表面温度は，積雪深や積雪期間など積雪状 況により大きな影響を受けるため，1 年間の地表面 温度の観測結果のみでは，誤った永久凍土分布の推 定をおこなう危険性がある（Imhof et al. 2000； Hoelzle et al. 2003). さらに，槍・穂高連峰南岳山 頂付近の風衝砂磁斜面においては，地温観測結果か ら永久凍土が存在する可能性が低いことが指摘され ている（高橋 1999）。ところが，細粒物質を欠いた 岩塊地では，冷気が集積・保持されやすい条件を備 えているとされている (Harris and Pedersen 1998; Matsuoka and Ikeda 2003).

そこで本研究では，飛騨山脈南部の槍・穂高連峰 における永久凍土の分布状況を明らかにするため， 気温，および細粒物質を欠いた岩塊地での地表面温 度の観測を，複数年にわたっておこなった。本稿で はその観測結果を示し，本山域における山岳永久凍 土の有無およびその分布状況を，気温・地温状況に 基づいて論じる.

\section{II 調 査地 域}

本研究の調査地域である槍・穂高連峰（図 1) は, 飛騨山脈の南部に位置している。調査対象地域には 標高 $2,700 \mathrm{~m}$ 以上の主稜線が南北に延びており, こ の主稜線上には槍ヶ岳（標高 $3,180 \mathrm{~m} ）$ をはじめ, 中岳 (標高 $3,084 \mathrm{~m}$ ), 南岳 (標高 $3,033 \mathrm{~m}$ ), 北穂 高岳（標高 $3,106 \mathrm{~m} ）$ など，標高 $3,000 \mathrm{~m}$ 以上の急 峻な山々が南北に連なっている。

この山域には最終水期の水河作用によって形成さ れた明瞭な水河地形が広く分布しており（五百沢 1979; Ito and Vorndran 1983; Aoki and Hasegawa 2003），急峻なカール壁や水食谷壁，比較的緩傾斜 のカール底や氷食谷底といった, 典型的な水食地形

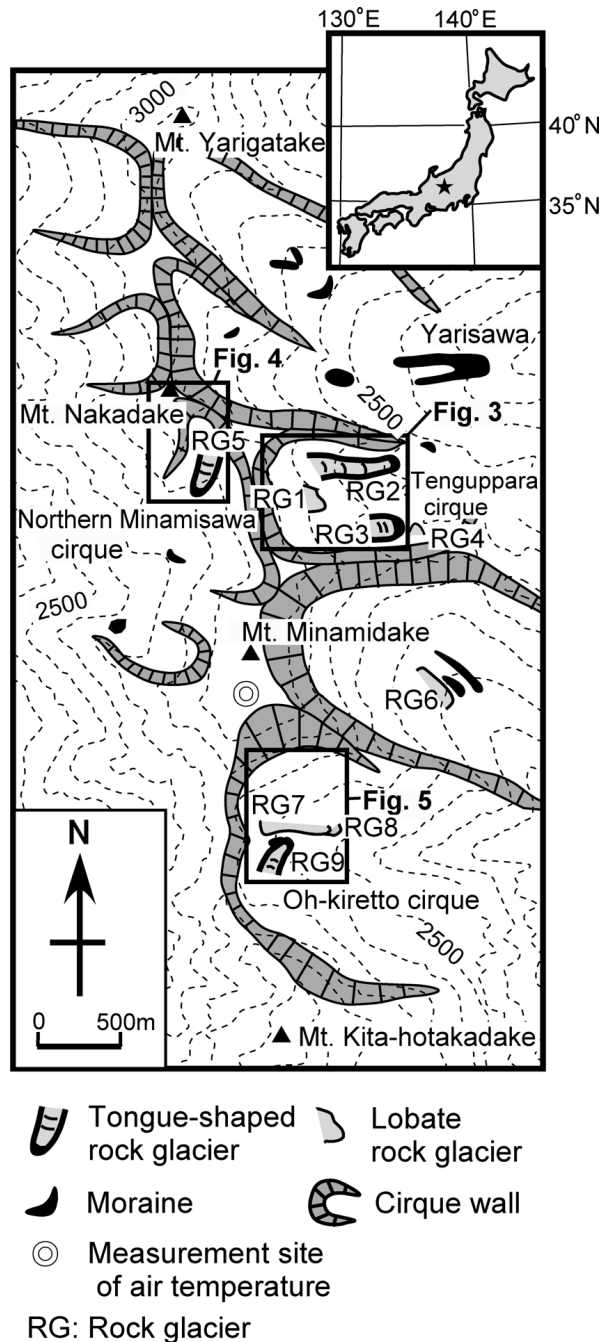

図 1 槍・穂高連峰周辺の水河地形, 岩石 氷河の分布と調査地域

Fig. 1 Distribution of glacial landforms and rock glaciers in the Yari-Hotaka Mountains, and study area

が見られる。

いくつかのカール内には，上面に斜面最大傾斜方 向に直交する畧・溝構造を有するかまぼこ状の形態 をなした岩塊地形や，周縁部に切れ目のない連続性 の良いリッジを持ち，その内側に同心円状の畧・溝 構造を有した岩塊地形などが存在する。それらの前 
縁部では，表層部がオープンワークの岩塊層，その 下部が細粒岩屑層または砂礫層から成る二層堆積構 造が認められる。そのような岩塊地形に認められる 形態的特徵や堆積構造は, 岩石水河の形態的特徵や 堆積構造と合致することから，それらの岩塊地形は 岩石水河と解釈されている（Shiki 1969; 式 1975; 青山 $2002 a ， b)$ 。 それらは，晚水期や完新世初期以 降の寒冷期に形成・発達したと推定されている (Aoyama 2005).

森林限界は標高 $2,500 \sim 2,600 \mathrm{~m}$ 付近にあり，森 林限界を越える地域は植生にそしい岩塊地・岩屑斜 面，岩壁が広い領域を占めており，植生はわずかに ハイマツや高山植物群落が点在するのみである。本 調査地域の地質は，前穂高溶結凝死岩や南岳凝死角 磁岩などの穂高安山岩類（原山 1990）から構成さ れている。

\section{III＼cjkstart観測方法および地表面温度観測地点の概要}

1. 気温および地表面温度の観測方法

気温および地表面温度観測には，ティアンドディ 社製の小型自記温度計 TR-52 を用いた。 TR-52 の測 定精度は, $-20 \sim 80^{\circ} \mathrm{C}$ の範囲内では $\pm 0.3^{\circ} \mathrm{C}$, $-20 \sim-40^{\circ} \mathrm{C}$ の範囲内では $\pm 0.5^{\circ} \mathrm{C}$ である。観測に 用いた機器については，観測前に精密温度計による 器差補正をおこなった。各観測地点の概要と観測期 間を表 1 に示し，各観測地点とその周囲の状況を図 2 に示した

気温観測は，槍・穂高連峰主稜線上にある南岳小 屋（標高 $2,975 \mathrm{~m} ）$ でおこなった（図 1, 図 2). 冬 季の積雪による測器の埋没を避けるため，測器は小 屋の壁面の地上高約 $5 \mathrm{~m}$ に設置した。直達日射の影 響を避けるため，外側をアルミ箔で覆った直径 75

表 1 気温および地温観測地点の概要と観測期間

Table 1 Description and observation periods of air and ground temperature monitoring sites

\begin{tabular}{|c|c|c|c|c|c|}
\hline Site & $\begin{array}{l}\text { Elevation } \\
\text { (m a.s.1.) }\end{array}$ & Aspect & Geomorhic features & $\begin{array}{l}\text { Dominant graine } \\
\text { size }(\mathrm{cm})\end{array}$ & Observation period \\
\hline \multicolumn{6}{|c|}{ Monitoring site of air temperature } \\
\hline $\begin{array}{l}\text { Minamidake } \\
\text { hut }\end{array}$ & 2975 & W & Periglacial smooth slope & - & 1 Oct. $2000-30$ Sept. 2005 \\
\hline \multirow{2}{*}{\multicolumn{6}{|c|}{$\begin{array}{l}\text { Monitoring sites of ground temperature } \\
\text { Tenguppara Cirque }\end{array}$}} \\
\hline & & & & & \\
\hline TE1 & 2810 & $\mathrm{E}$ & Gentle slope on rock glacier & $30-100$ & 1 Oct. $2000-30$ Sept. 2004 \\
\hline TE2 & 2710 & $\mathrm{NE}$ & Lobe on rock glacier & $30-100$ & 1 Oct. $2004-30$ Sept. 2005 \\
\hline TE3 & 2670 & $\mathrm{E}$ & Ridge on rock glacier & $10-200$ & 1 Oct. $2004-30$ Sept. 2005 \\
\hline \multicolumn{6}{|c|}{ Northern Minamisawa Cirque } \\
\hline NM1 & 2960 & S & Ridge on rock glacier & $30-100$ & 1 Oct. $2000-30$ Sept. 2004 \\
\hline NM2 & 2950 & S & Furrow on rock glacier & $30-100$ & 7 Oct. $2002-22$ Sept. 2004 \\
\hline NM3 & 2950 & S & Ridge on rock glacier & $30-100$ & 7 Oct. $2002-22$ Sept. 2004 \\
\hline NM4 & 2940 & $\mathrm{~S}$ & Furrow on rock glacier & $30-100$ & 1 Oct. $2004-30$ Sept. 2005 \\
\hline NM5 & 2940 & $\mathrm{~S}$ & Ridge on rock glacier & $30-100$ & 1 Oct. $2004-30$ Sept. 2005 \\
\hline \multicolumn{6}{|c|}{ Oh-kiretto Cirque } \\
\hline OK1 & 2620 & $\mathrm{E}$ & Gentle slope on rock glacier & $30-70$ & 7 Oct. $2002-6$ Oct. 2003 \\
\hline $\mathrm{OK} 2$ & 2610 & $\mathrm{E}$ & Lobe on rock glacier & $30-70$ & 1 Oct. $2000-22$ Sept. 2004 \\
\hline OK3 & 2550 & SE & Flat surface on rock glacier & $50-100$ & 7 Oct. $2002-22$ Sept. 2004 \\
\hline OK4 & 2570 & $\mathrm{NE}$ & Ridge on rock glacier & $30-100$ & 1 Oct. 2002-22 Sept. 2004 \\
\hline OK5 & 2600 & $\mathrm{NE}$ & Lobe on rock glacier & $20-50$ & 1 Oct. $2002-22$ Sept. 2004 \\
\hline OK6 & 2620 & $\mathrm{~N}$ & Lobe on rock glacier & $30-100$ & 1 Oct. $2000-22$ Sept. 2004 \\
\hline OK7 & 2640 & $\mathrm{~N}$ & Lower part of talus slope & $30-100$ & 1 Oct. $2002-30$ Sept. 2003 \\
\hline
\end{tabular}



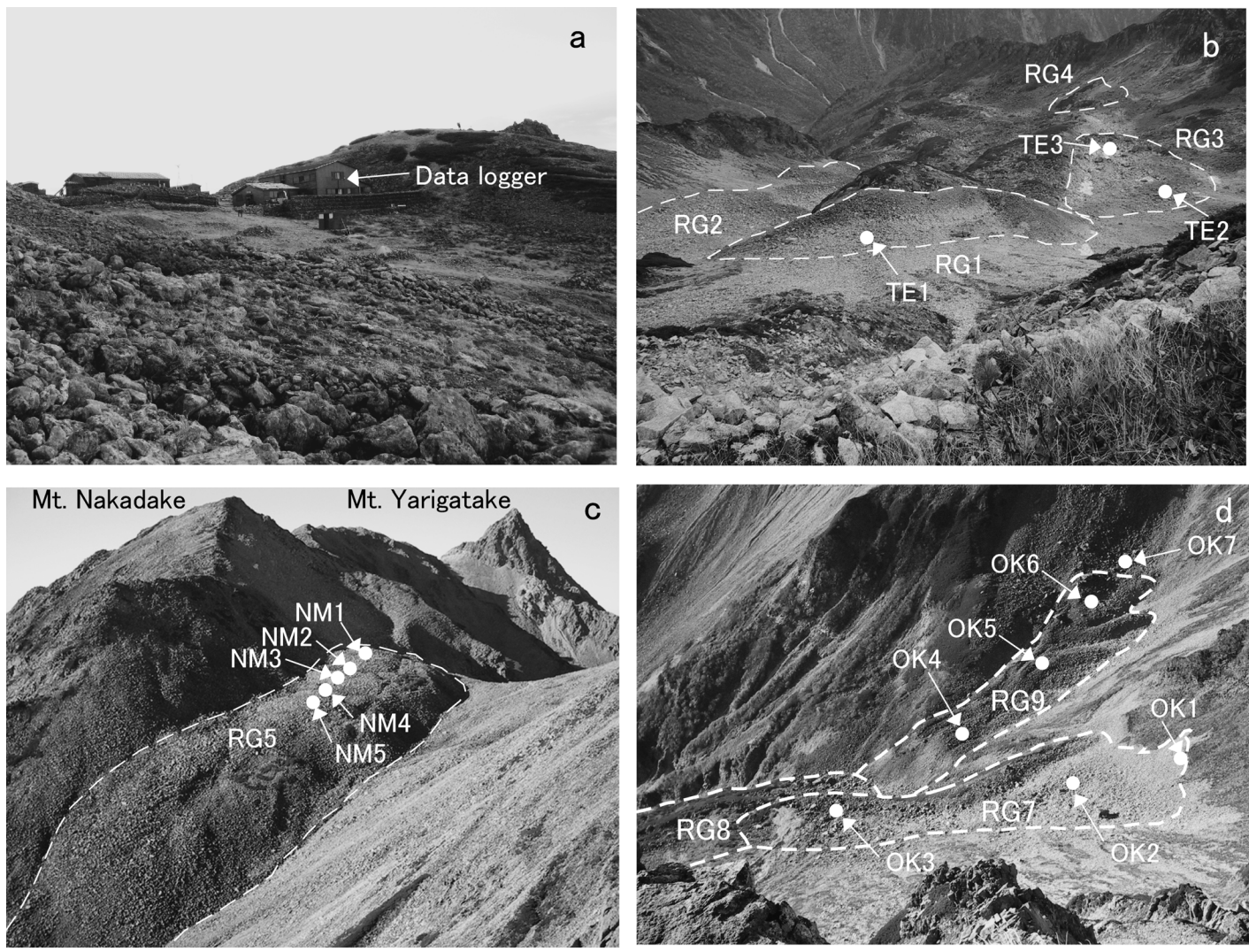

図 2 気温・地温観測地点

$\mathrm{a}$ ：気温観測地点（南岳小屋）b：天狗原カールにおける地温観測地点 $\mathrm{c}$ ：南沢北カールにおける地温観測地点 $\mathrm{d}$ ：大キレット カールにおける地温観測地点

Fig. 2 Monitoring sites of air and ground temperature

$\mathrm{a}$ : Monitoring site of air temperature (Minamidake hut); b: monitoring sites of ground temperature on the Tenguppara cirque; $c$ : monitoring sites of ground temperature on the northern Minamisawa cirque; $d$ : monitoring sites of ground temperature on the Oh-kiretto cirque.

$\mathrm{mm}$ と $50 \mathrm{~mm}$ の塩化ビニール製パイプ（長さはとも に250 mm）を重ね, その内部にセンサーを固定し た。観測は自然通風でおこなった。観測期間は 2000 年 10 月 1 日 2005 年 9 月 30 日までの 5 年間であ り, 60 分間隔で気温の測定・記録をおこなった. 地表面温度観測は, 炅狗原カールで 3 地点 (TE1〜 TE3), 南沢北カールで5 地点 (NM1 NM5), 大キレットカールで 7 地点 $(\mathrm{OK} 1 \sim \mathrm{OK} 7)$ の合計 15 地点でおこなった（図 2, 図 3, 図 4, 図 5). 観測 地点は岩石水河と崖錐斜面上であり, 地表面は細粒
物質を欠いた無植生の岩塊から成っている。直達日 射の影響を避けるため, 測器は直達日射の当たらな い地表面礫間の空隙部分に設置した。観測期間は, 表 1 に示した通りである。各地点において，観測期 間中, 60 分間隔で地温の測定・記録をおこなった。

2. 地表面温度観測地点の地形および地表面状態 天狗原カール内部には四つの岩石水河（RG1〜 RG4）が存在する（図 2, 図 3)。TE1 は，カール壁 直下の東向き崖錐斜面基部にある岩石水河（RG1） 


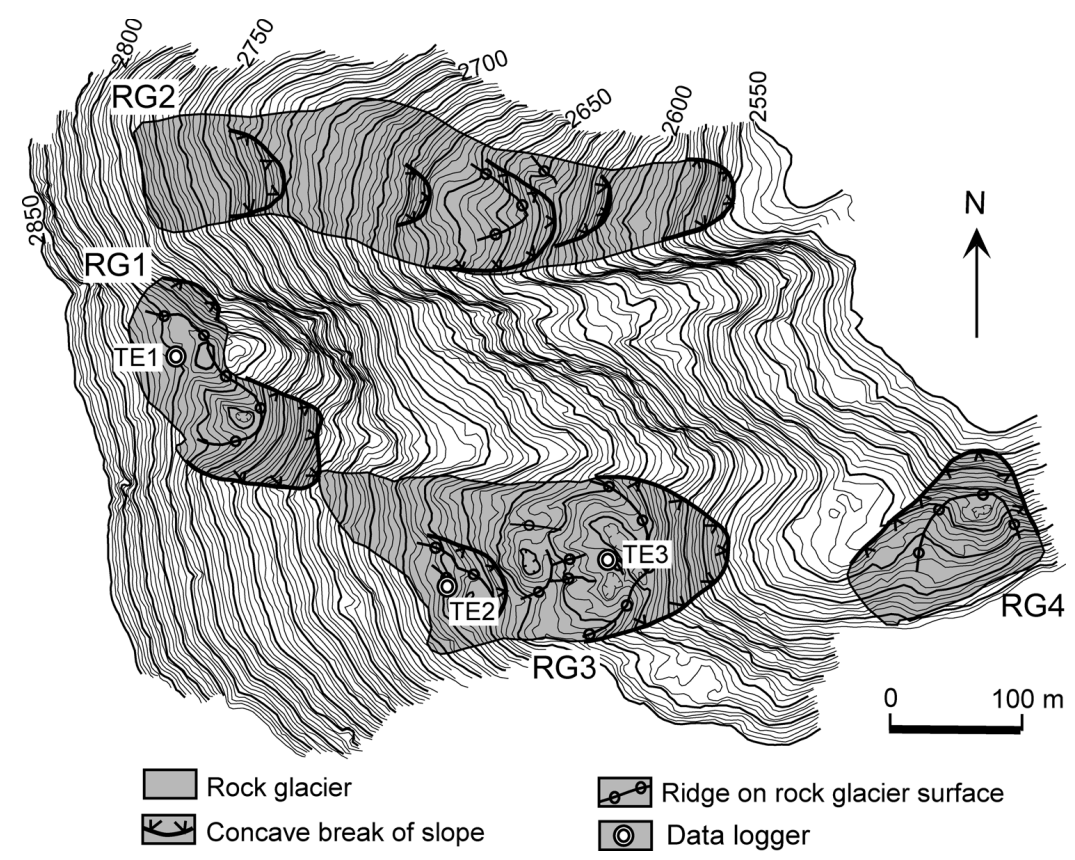

等高線間隔は $2 \mathrm{~m}$.

図 3 天狗原カールの地形と地表面温度観測地点

林野庁発行 1:16,000 空中写真（1988 年 10 月 11 日撮影, C26A-16, 17） から解析図化機（ライカ 社製 SD3000）を用いて作成.

Fig. 3 Contoured morphological map of the Tenguppara cirque showing the locations of miniature data loggers

Contour intervals are $2 \mathrm{~m}$.

上に位置する。この岩石水河の前縁部は，切れ目の ない $\mathrm{M}$ 字状に湾曲したリッジとなっており，中央部 には閉塞凹地が存在する。TE1は，この閉塞凹地と その上部の崖錐斜面との間の，東向きの凹型緩斜面 上に位置する。地表面は，長径 30 100 cm の前穂 高溶結凝灰岩の角磉から成っており，礫間を充填す る細粒物質は存在しない。TE2 は，天狗原カール内 部の南側のカール底に存在する岩石水河（RG3）の 上部に位置しており，凸型のふくらみをもったロウ ブ上にある。地表面は長径 $30 \sim 100 \mathrm{~cm}$ の南岳凝灰 角礫岩の角礫から成っており, 細粒物質は存在しな い. TE3 はこの岩石水河（RG3）の下部に位置す る. RG3 下部には複数の閉塞凹地と欲状の高まりが 見られ，TE3 は岩石水河末端付近の畧上に位置す

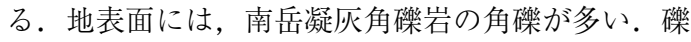

は，長径 $10 \sim 200 \mathrm{~cm}$ のものが多いが，最大 $8 \mathrm{~m}$ に 達するものもあり，淘汰は悪い.

NM1 5 は，南沢北カールに存在する舌状の岩石 水河（RG5）上に位置する（図 2 , 図 4)。この 5 地 点とも地表面は長径 $30 \sim 100 \mathrm{~cm}$ の前穂高溶結凝灰 岩の角磁から成っており, 細粒物資は存在しない。 この岩石水河上には，多くの岩石水河の形態的特徵 として見られる，斜面最大傾斜方向に直交する站状 の高まりと，断面形が $\mathrm{V}$ 字状の溝（Wahrhaftig and Cox 1959；Barsch 1996）が存在している. NM1, NM3，NM5 は䇉状の高まり上に位置し, NM2 と $\mathrm{NM} 4$ は深さ $1.5 \mathrm{~m}$ 程度の $\mathrm{V}$ 字状の溝の底に位置す る.

大キレットカール内部には, 南岳側カール壁直下 の崖錐（南東向き）斜面基部に二つの耳たぶ状の岩 


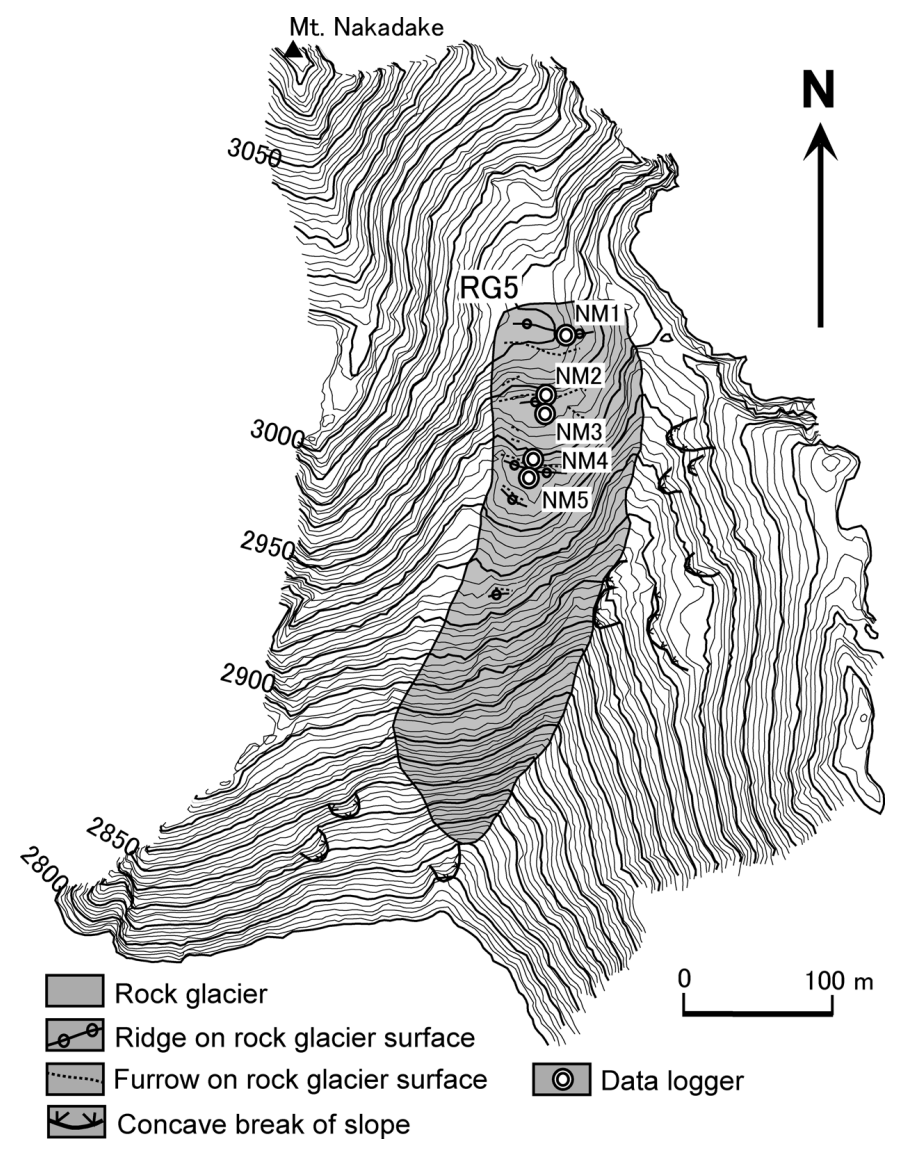

図 4 南沢北カールの地形と地表面温度観測地点

等高線間隔は $2 \mathrm{~m}$.

林野庁発行 $1: 16,000$ 空中写真（1988 年 10 月 11 日撮影, C26A-16, 17) 加解 析図化機（ライカ社製 SD3000）を用いて作成。

Fig. 4 Contoured morphological map of the northern Minamisawa cirque showing the locations of miniature data loggers

Contour intervals are $2 \mathrm{~m}$.

石水河（RG7, RG8）が，北穂高岳側カール壁直下 の崖錐（北向き）斜面基部には一つの舌状岩石水河 （RG9）がある（図 2，図 5).

OK1，OK2，OK3 は，いずれも起伏の小さい RG7 上に位置する，その中で，OK2 は岩石水河上に形成 されている規模の小さなロウブの上にある. OK1 と OK2 の地表面は，ともに長径 $30 \sim 70 \mathrm{~cm}$ の前穂高溶 結凝扊岩の角礫から成り, 細粒物質を欠いている。 OK3 の地表面は南岳凝扊角磉岩と前穂高溶結凝扊岩
の角䃯から成るが，南岳凝灰角磁岩の方がやや多く， 細粒物質は存在しない. OK3 の表面磉は他の地温測 定地点のそれよりも大きく，表面礫の長径は 50 100 cm のものが多いが，長径 7 8 m の巨礫も 散在している.

OK4，OK5，OK6 はRG9 上にあり，OK7 はその上 の崖錐斜面下部に位置する．RG9 上は起伏に富んで おり，複雑な表面形態を呈している。OK4 は RG9 末端付近の斜面最大傾斜方向と平行（縦断方向）に 


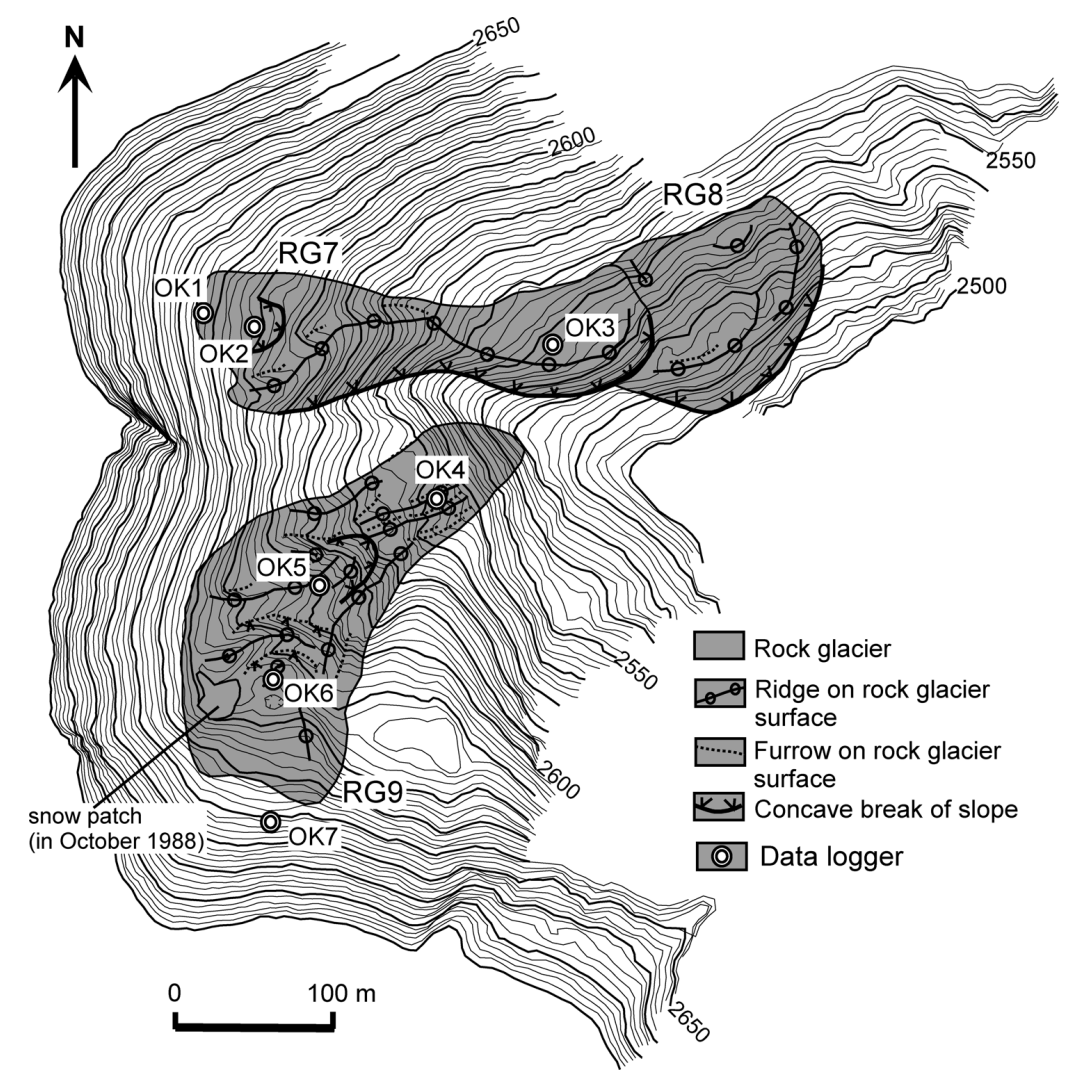

図 5 大キレットカールの地形と地温観測地点

等高線間隔は $2 \mathrm{~m}$.

林野庁発行 1:16,000 空中写真（1988 年 10 月 11 日撮影, C27-18, 19） から解析図化機（ライ 力社製 SD3000) を用いて作成.

Fig. 5 Contoured morphological map of the Oh-kiretto cirque showing the locations of miniature data loggers

Contour intervals are $2 \mathrm{~m}$.

延びるリッジ上に位置しており，OK5 は RG9 中部 のロウブ上に位置する。 OK6 は RG9 最上部のロウ ブ上に位置する。 OK4, OK7 の地表面は, 細粒物質 を欠いた前穂高溶結凝灰岩の角碟から成っており, OK4, OK6 と OK7 では長径 30 100 cm の礫が卓越 し, OK5 では長径 20 50 cm の礫が卓越している.

\section{IV 観 測 結 果}

\section{1. 気温状況}

南岳小屋に打ける観測期間中の気温推移状況を図 6 に, 各月の平均気温, 年平均気温, 気温年較差,
凍結指数および融解指数を表 2 に示した．観測期間 (10月から翌年 9 月) 内に扔ける気温の推移を見て みると，年によって若干の変動はあるものの，ほぼ 同じょうに推移している．9月下旬から 10 月上旬に 日最低気温が $0{ }^{\circ} \mathrm{C}$ を下回るようになり，10月下旬か ら 11 月上旬には日最高気温も $0^{\circ} \mathrm{C}$ を回るように なる。それ以降，日最高気温が $0^{\circ} \mathrm{C}$ を回る日は 2 月下旬までほとんど出現せず，氷点下で推移してい る. 4 月に入ると日最高気温が $0^{\circ} \mathrm{C}$ を上回る日がほ とんどとなり，6月中旬から下旬以降は日最低気温 も $0^{\circ} \mathrm{C}$ を上回り, 秋季まで $0^{\circ} \mathrm{C}$ 以上で推移してい 

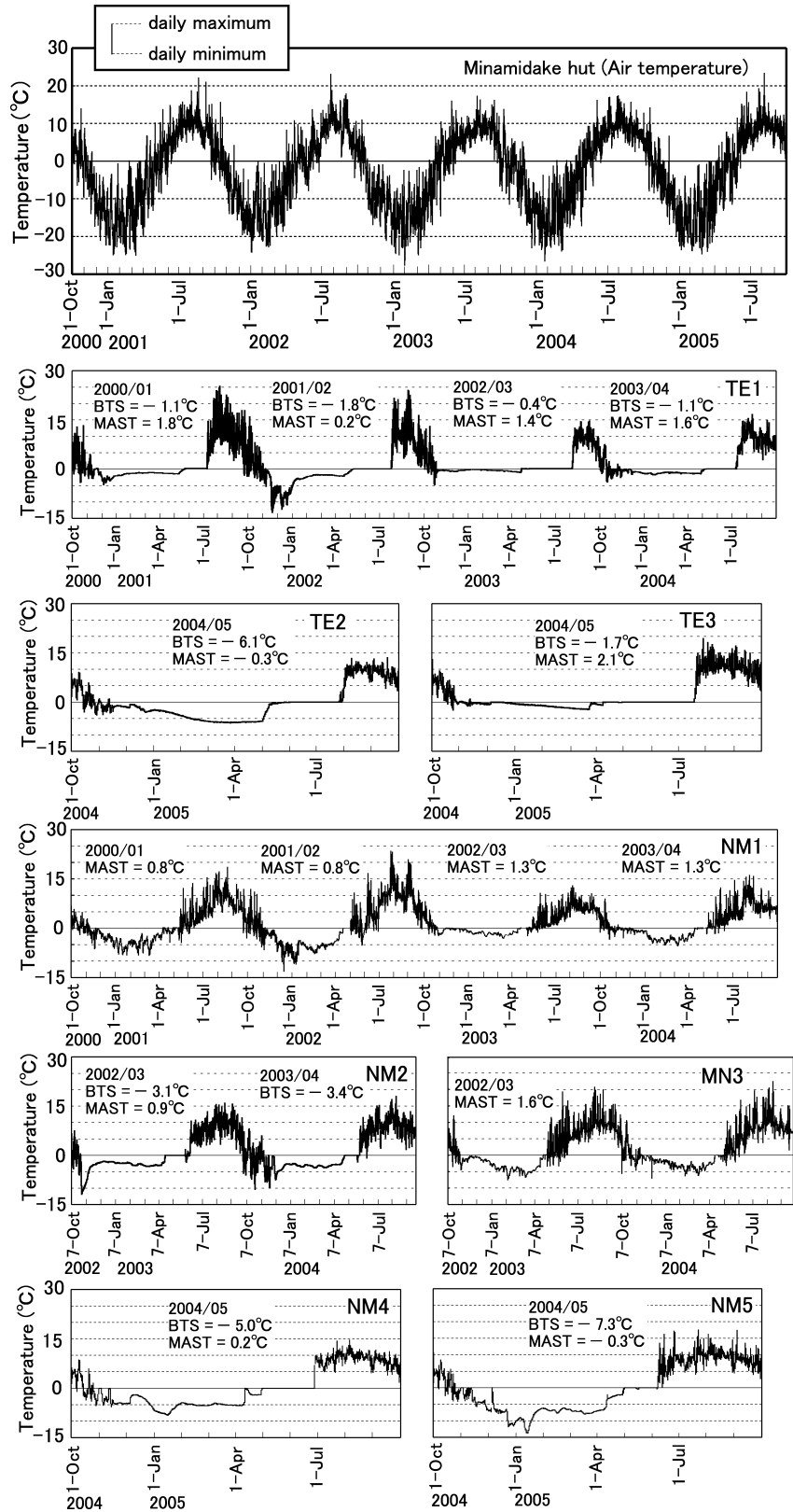

図 6 南岳小屋（標高 $2,975 \mathrm{~m}$ ）における気温と, 天狗原カールお

よび南沢北カール内の観測地点における地表面温度の推移

BTS: 冬季積雪底地表面温度（3 月の平均值） MAST: 年平均地表面温度.

Fig. 6 Variation in daily air temperature at the Minamidake hut (2,975 $\mathrm{m}$ a.s.1.) and ground surface temperature at the monitoring sites on the Tenguppara cirque and the northern Minamisawa cirque

BTS: bottom temperature of the winter snow cover; MAST: mean annual ground surface temperature. 
表 2 南岳小屋（標高 2,975 m）における気温状況（2000 年 10 月～2005 年 9 月）

Table 2 Summary of air temperature monitoring from October 2000 to September 2005 at the Minamidake hut (2,975 m a.s.1.)

\begin{tabular}{|c|c|c|c|c|c|c|c|c|c|c|}
\hline & Oct. & Nov. & Dec. & Jan. & Feb. & Mar. & Apr. & May & Jun. & Jul. \\
\hline $2000 / 01$ & 1.5 & -4.1 & -12.6 & -15.9 & -14.6 & -11.9 & -5.3 & 0.8 & 5.2 & 9.9 \\
\hline $2001 / 02$ & 1.0 & -7.2 & -13.9 & -14.1 & -13.9 & -10.0 & -3.1 & 0.4 & 4.0 & 10.5 \\
\hline $2002 / 03$ & -0.7 & -9.9 & -11.4 & -16.2 & -14.0 & -12.7 & -3.3 & 2.2 & 5.3 & 7.2 \\
\hline $2003 / 04$ & -0.7 & -2.7 & -12.2 & -16.6 & -14.0 & -11.5 & -4.8 & 2.8 & 6.4 & 9.5 \\
\hline $2004 / 05$ & 1.7 & -4.8 & -10.8 & -15.9 & -15.1 & -12.4 & -4.8 & -0.7 & 6.5 & 8.7 \\
\hline & \multicolumn{2}{|c|}{$\begin{array}{c}\text { Mean } \\
\left({ }^{\circ} \mathrm{C}\right)\end{array}$} & \multicolumn{2}{|c|}{$\begin{array}{c}\text { Annual range } \\
\left({ }^{\circ} \mathrm{C}\right)\end{array}$} & \multicolumn{3}{|c|}{$\begin{array}{l}\text { Freezing index } \\
{ }^{\circ} \mathrm{C} \cdot \text { days }\end{array}$} & \multicolumn{3}{|c|}{$\begin{array}{c}\text { Thawing index } \\
{ }^{\circ} \mathrm{C} \cdot \text { days }\end{array}$} \\
\hline $2000 / 01$ & \multicolumn{2}{|c|}{-2.5} & \multicolumn{2}{|c|}{25.8} & \multicolumn{3}{|c|}{2013.4} & \multicolumn{3}{|c|}{1101.3} \\
\hline $2001 / 02$ & \multicolumn{2}{|c|}{-2.5} & \multicolumn{2}{|c|}{24.6} & \multicolumn{3}{|c|}{1944.9} & \multicolumn{3}{|c|}{1033.1} \\
\hline $2002 / 03$ & \multicolumn{2}{|c|}{-3.1} & \multicolumn{2}{|c|}{25.6} & \multicolumn{3}{|c|}{2147.9} & \multicolumn{3}{|c|}{1025.9} \\
\hline $2003 / 04$ & \multicolumn{2}{|c|}{-2.2} & \multicolumn{2}{|c|}{26.2} & \multicolumn{3}{|c|}{ 1967. 7} & \multicolumn{3}{|c|}{1151.8} \\
\hline $2004 / 05$ & \multicolumn{2}{|c|}{-2.5} & \multicolumn{2}{|c|}{25.6} & \multicolumn{3}{|c|}{2004.1} & \multicolumn{3}{|c|}{1095.1} \\
\hline
\end{tabular}

$<$.

観測期間内に打ける日最高気温と日最低気温の極 值はそれぞれ $23.4^{\circ} \mathrm{C}\left(2005\right.$ 年 8 月 5 日),$-27.8^{\circ} \mathrm{C}$ （2003 年 1 月 29 日）であった。観測期間内に扔ける 各年の最暖月は 7 月または 8 月にあらわれている. 最暖月平均気温を見てみると, 2002 年の最暖月（7 月）が最も高く $\left(10.5^{\circ} \mathrm{C}\right), 2003$ 年の最暖月（8 月） が最も低かった $\left(9.4^{\circ} \mathrm{C}\right)$. 観測期間における各年の 最寒月は毎年 1 月にあらわれた。最寒月平均気温を 見てみると, 2004 年 1 月が最も低く $\left(-16.6^{\circ} \mathrm{C}\right)$, 2002 年 1 月が最も高かった $\left(-14.1^{\circ} \mathrm{C}\right)$. 気温の年 較差は $2003 \sim 2004$ 年が最も大きく $\left(26.2^{\circ} \mathrm{C}\right)$, $2001 \sim 2002$ 年が最も小さかった $\left(24.6^{\circ} \mathrm{C}\right)$. 観測期 間内の年平均気温は $-2.2^{\circ} \mathrm{C} \sim-3.1^{\circ} \mathrm{C}$ であり, 凍結 指数と融解指数はそれぞれ $1944.9 \sim 2147.9^{\circ} \mathrm{C} \cdot$ days, 1025. 9 1151. $8^{\circ} \mathrm{C} \cdot$ days であった.

\section{2. 地表面温度状況}

天狗原カールおよび南沢北カール内の各観測地点 に打ける地表面温度の推移を図 6 に，大キレット カール内における各観測地点のそれについては図 7
に示した.

冬季季節風に対して風背側となる主稜線の東側に 位置する観測地点（TE1 3, OK1 7） と，主稜線 西側の南沢北カールに存在する岩石水河（RG5）上 の溝状地（NM2，NM4）および主稜線上付近にある その岩石水河の上端から約 $20 \mathrm{~m}$ ほど斜面下方にあ る岩石水河中部のリッジ上（NM5）では，地表面温 度は秋季から初冬にかけてその日較差が次第に小さ くなりつつ徐々に低下していき，冬季には顕著な日 変化が生じない状態で $0^{\circ} \mathrm{C}$ 以下で推移した。地表面 温度は 4 月または 5 月上旬になると $0^{\circ} \mathrm{C}$ まで急激に 上昇し，それ以降初夏（6月中旬～8月上旬）にか けて $0^{\circ} \mathrm{C}$ を保ち, 温度変化のない状態で推移した。 それらの地点のうち, TE2, NM2, NM4, NM5, OK2, OK3, OK4, OK5, OK6, OK7 では，冬季におけ る地表面温度の顕著な日変化が生じない期間には, 地表面温度は $0^{\circ} \mathrm{C}$ を大きく下回り, $-2^{\circ} \mathrm{C}$ 以下で推 移した，特に，OK3 では，地表面温度の顕著な日変 化が生じなくなった後も地表面温度の低下傾向が続 き， 3 月には $-9^{\circ} \mathrm{C}$ をやや下回るまで低下した

一方，TE1，TE3，OK1では，初冬に地表面温度 

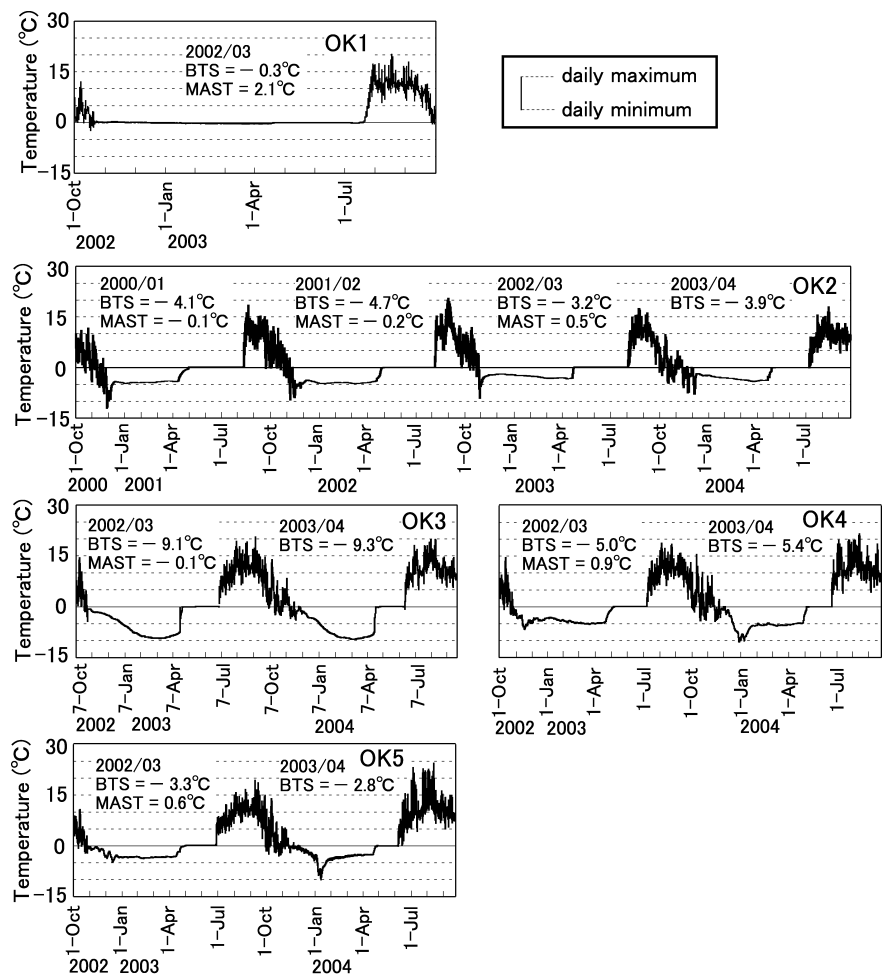

$2002{ }^{\top} 2003$
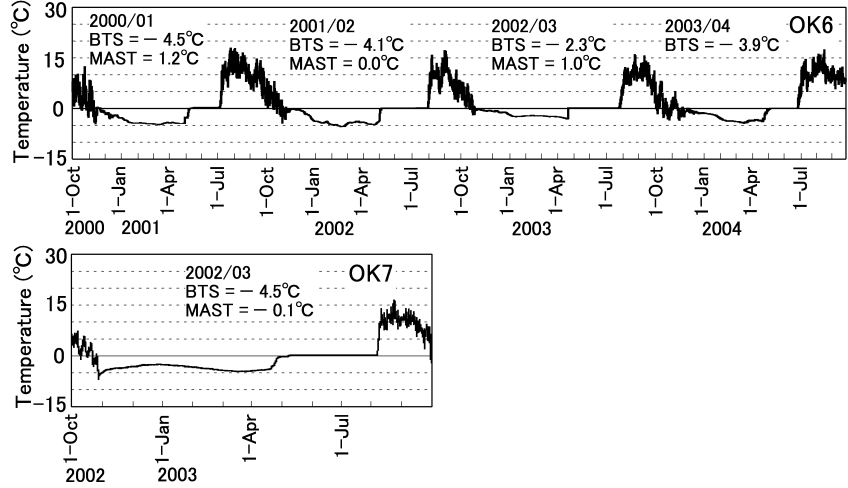

図 7 大キレットカール内の観測地点における地表面温度の推移 BTS: 冬季積雪底温度 (3 月の平均值) MAST: 年平均地表面温度.

Fig. 7 Variation in daily ground surface temperature at the monitoring sites on the Oh-kiretto cirque

BTS: bottom temperature of the winter snow cover; MAST: mean annual ground surface temperature.

の日変化が見られなくなって以降，地表面温度の顕

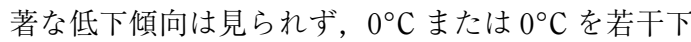
回る值で推移した。TE1 と TE3 では，地表面温度 の日変化が見られなくなった初冬から晚冬季にかけ
て，地表面温度はほぼ $0^{\circ} \mathrm{C}$ から $-2^{\circ} \mathrm{C}$ の間で推移し た。 OK1 では， 2002 年 10 月下旬から 2003 年の 7 月下旬までは，日変化がほとんどない状態で $0^{\circ} \mathrm{C} ま$ たは $0^{\circ} \mathrm{C}$ に近い值で推移した. 


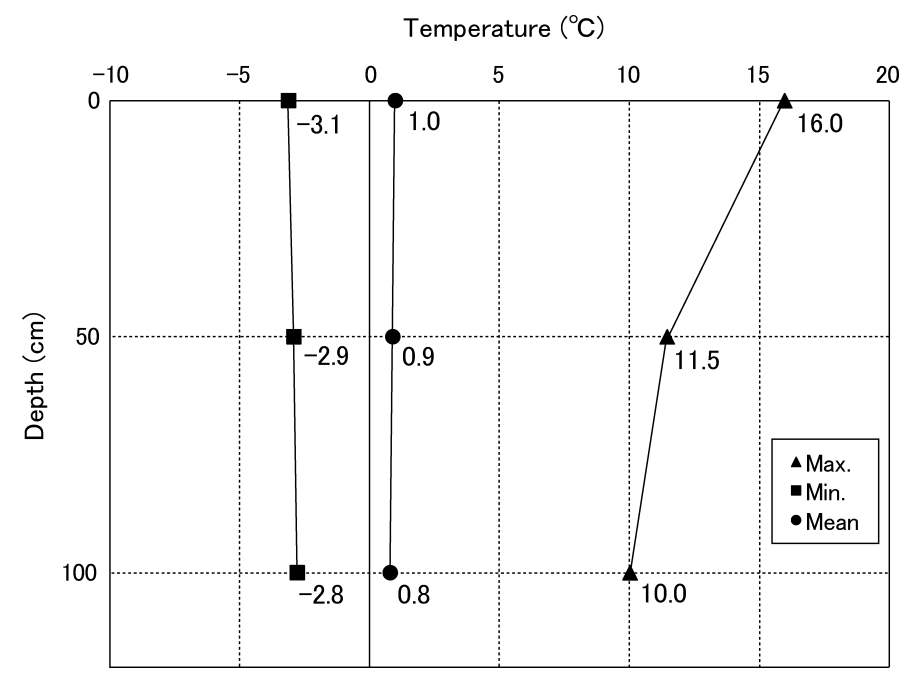

図 8 大キレットカール内 OK6 における地温断面（2002 年 10 月 1 日 2003 年 9 月 30 日)

Fig. 8 Profiles of the ground temperatures at site OK6 during the period from October 1, 2002, to September 30, 2003

冬季季節風に対して風衝側となる主稜線西側の南 沢北カール内の岩石水河（RG5）上部のリッジ上に 位置する NM1 と NM3 における地表面温度は, 上述 の地点とは異なり, 年間を通して日変化が生じてお り，冬季にも気温変化と同調するように明瞭な日変 化を伴いながら，ほぼ $0^{\circ} \mathrm{C}$ 以下で推移した（図 6).

大キレットカール内の OK6 では, 2002 年 10 月 2003 年 9 月までの 1 年間ではあるが，地表面温 度に加え, $50 \mathrm{~cm}$ 深と $100 \mathrm{~cm}$ 深の地温観測もおこ なった。その結果, 深度が大きくなるほど地温年変 化の幅は小さくなり，年平均地温も地表面 $(0 \mathrm{~cm}$ 深) で $1.0^{\circ} \mathrm{C}, 50 \mathrm{~cm}$ 深で $0.9^{\circ} \mathrm{C}, 100 \mathrm{~cm}$ 深で $0.8^{\circ} \mathrm{C}$ と深度が大きくなるほど低い值を示した（図 8 ).

\section{$\mathrm{V}$ 考察}

\section{1. 気温状況からみた永久凍土環境}

広域的なスケールで見た場合, 不連続山岳永久凍 土帯下限高度は, 年平均気温 $-2^{\circ} \mathrm{C}$ の等温線とほぼ 一致することが知られている（Haeberli 1983,
1985；Barsch 1996). 南岳小屋における年平均気温 は，上述のように観測期間内の 5 年間いずれの年も $-2^{\circ} \mathrm{C}$ 以下であった。また，南岳小屋における観測 期間内の凍結・融解指数を Harris（1981）のダイア グラムに適用すると，観測期間内のいずれの年の值 も，不連続永久凍土帯の気温条件に相当している. また, 藤井（1980）は，山岳永久凍土下限高度にお ける年平均気温は $-2^{\circ} \mathrm{C} \sim-4^{\circ} \mathrm{C}$ にあり, 山岳永久凍 土の存在条件は, 最暖月気温 $11^{\circ} \mathrm{C}$ 以下, 気温年較 差 $30^{\circ} \mathrm{C}$ 以下であることを指摘している．南岳小屋 に打ける気温観測結果は，そのような山岳永久凍土 存在の気温条件を満たしている。これらのことから， 槍・穂高連峰主稜線部が不連続山岳永久凍土带の気 温条件下にあることは確実である。

2. 地表面温度状況から推定される永久凍土分布 山岳永久凍土の分布を推定する手法の一つとして, 冬季積雪底地表面温度（BTS：Bottom temperature of the winter snow cover) を用いた手法があ 
る (Haeberli 1973)。この手法は, 厚い積雪（約 $80 \mathrm{~cm}$ 以上）のある地点では, 積雪の熱伝導率の低 さによって地表面が外気の影響から遮断されると いった，積雪の断熱効果を利用したものである．積 雪下の地表面温度は冬の終わりに地中温度と平衡状 態に近づく，という前提で永久凍土の有無を推定す る.この $\mathrm{BTS}$ 值に基づくと, $-3^{\circ} \mathrm{C}$ 以下であれば永 久凍土が存在する可能性が高く, $-3^{\circ} \mathrm{C}$ から $-2^{\circ} \mathrm{C}$ の範囲内であれば存在する可能性があり,$-2^{\circ} \mathrm{C}$ 以 上の場合には存在しない, ということが, アルプス やスカンジナビア半島などでの調査から経験的に知 られている (Haeberli 1973; Haeberli and Patzelt 1982; King 1983; Hoelzle 1992; Hoelzle et al. 1993)。このBTS を用いた永久凍土探査はそれらの 山域のみならず，スペイン・シエラネバダ山脈 (Gómez et al. 2001)，コロラド・ロッキー山脈 (Janke 2005)，北海道の大雪山（Ishikawa and Hirakawa 2000） や日高山脈（石川ほか 2002； Ishikawa 2003）など，世界のさまざまな山域にお いて適用されている。

年平均地表面温度も, 永久凍土の有無の推定に有 効な指標であり, 永久凍土が存在する場合には, そ の值は $0^{\circ} \mathrm{C}$ 以下となる (Gądek and Kędzia 2008). また，スイスアルプスでは，現在永久凍土の衰退が 進行している停滞型の岩石水河上に扔ける年平均地 表面温度が $0{ }^{\circ} \mathrm{C}$ をや上回ることもあるが，その場 合でも $1^{\circ} \mathrm{C}$ 前後よりは低い值を示すことが報告され ている (Ikeda and Matsuoka 2002; Ikeda 2006). 本研究においても, 地表面温度の観測結果から得 られた BTS 值や年平均地表面温度に基づいて, 槍 ・ 穂高連峰に抢ける山岳永久凍土の有無に関する推定 をおこなう。

主稜線の東側に位置する観測地点（TE1 3, OK1 7） と，主稜線西側の南沢北カールに存在する 岩石水河（RG5）上に位置する NM2, NM4, NM5 で は，秋季から初冬にかけて地表面温度はその日較差
が次第に小さくなりつつ低下し，冬季には明瞭な日 変動が生じない状態で $0^{\circ} \mathrm{C}$ 以下で推移した。 これは, 秋季から初冬にかけてはまだ積雪深が小さいため, 寒冷な外気の影響を受けて地表面が冷却されている が，積雪深が次第に大きくなり，積雪の断熱効果に よって地表面が寒冷な外気の影響から遮断される程 度の積雪深（約 $80 \mathrm{~cm}$ 以上; Haeberli 1973）に達 したことを示しているのであろう。したがって，そ れらの地点は, 永久凍土の有無を推定する指標とし てBTS 值を用いる際の積雪条件を満たしていると判 断できる.

それらの地点における地表面温度は，4月または 5 月上旬になるとその值が $0^{\circ} \mathrm{C}$ まで急激に上昇し， それ以降初夏（6月中旬～8 月上旬）まで温度変化 がなく, $0^{\circ} \mathrm{C}$ を保った状態で推移している。これは， 冬の終わりから春季にかけての気温の上昇に伴って, 積雪の融解が進むことにより積雪温度が全層にわ たって融解点に達し, 地表面温度は積雪が消失する まで外気の影響からは遮断される一方, 積雪の融解 潜熱の影響を受けていることを示しているのであろ う.そのため, 本研究では, 融雪の影響が積雪底に 達する直前の 3 月の地表面温度の平均值を BTS 值 として用いる.

それらの地点のうち, TE2, NM2, NM4, NM5, OK2, OK3, OK4, OK5, OK6, OK7 では, BTS 值が $-2{ }^{\circ} \mathrm{C}$ を回っていたことから，それらの地点には 永久凍土が存在している可能性がある。中でも, 南 沢北カールの岩石水河上の NM2 や, 大キレットカー ル内部の南〜南東向き崖錐斜面基部に存在する岩石 水河（RG7）上に位置する OK2 と OK3，大キレッ トカール内の北向き崖錐斜面基部からカール底にか けて存在する岩石水河上（RG9）に位置する OK4， $\mathrm{OK} 6$ の各地点では, 複数年の BTS 值が $-3^{\circ} \mathrm{C}$ 以下 を示したため, それらの地点には永久凍土が存在す る可能性は高い。

OK3 に扔りる冬季地表面温度は, 日変化が見られ 
なくなった後も低下傾向が続き, BTS 值は $-9^{\circ} \mathrm{C} を$ やや下回り, 他地点よりも大幅に低い值を示した. その原因として, 積雪面から露出した鿬の関与が考 えられる。

OK3 は他地点よりも表面礫の礫径が大きく, 付近 には長径 7 8 m の巨磁も散在している。ノルウェー 中央部の岩塊地では, 冬季にも積雪面上に露出して いる粗大礫が寒冷な外気によって冷却され，その粗 大礫を通した表面岩塊層の冷却が生じていることが 指摘されている (Juliussen and Humlum 2008). 本 調査地域の OK3 周辺でも, 巨磦が雪面上に露出し, それを通して表面岩塊層が泠却された可能性がある. このように, OK3 では厚い積雪下においても冬季地 表面温度の顕著な低下が生じていることから，永久 凍土の形成には有利な地温環境下にあり，永久凍土 が存在している可能性が高い.

$50 \mathrm{~cm}$ 深と $100 \mathrm{~cm}$ 深の地温観測をおこなった OK6 に関しては, $50 \mathrm{~cm}$ 深から $100 \mathrm{~cm}$ 深の地温勾配を $100 \mathrm{~cm}$ 以深に外抻すると, 最高地温は $433 \mathrm{~cm}$ 深で $0^{\circ} \mathrm{C}$ となり, 年平均地温は $500 \mathrm{~cm}$ 深で $0^{\circ} \mathrm{C}$ となる. このことからも, OK6 における永久凍土存在の可能 性を指摘できる。

また，TE2，NM5，OK7 では，観測期間が 1 年間 のみであるが, BTS 值がそれぞれ $-5.6^{\circ} \mathrm{C},-7.3^{\circ} \mathrm{C}$, $-4.1^{\circ} \mathrm{C}$ と $-3^{\circ} \mathrm{C}$ を下回り, 年平均地表面温度もそ れぞれ $-0.3^{\circ} \mathrm{C},-0.3^{\circ} \mathrm{C},-0.1^{\circ} \mathrm{C}$ と $0^{\circ} \mathrm{C}$ を回って いた。このことから, TE2, NM5, OK7 にも永久凍 土が存在する可能性は高いと判断される.

一方, TE1, TE3, OK1 では, 積雪の断熱効果に よって初冬に地表面温度の日変化が見られなくなっ て以降, 冬季の地表面温度の顕著な低下は生じてい ない. TE1では, 観測期間のいずれの年も BTS 值 が $-2{ }^{\circ} \mathrm{C}$ 上回っていた。 TE 3 とK1における BTS 值も $-2^{\circ} \mathrm{C}$ を回る值であり，それぞれ $-1.6^{\circ} \mathrm{C},-0.3^{\circ} \mathrm{C}$ であった.

このように, TE1, TE3 や OK1 では, 厚い積雪に
覆われて以降, 冬季地表面温度の顕著な低下は生じ ておらず，冬季における地表面の冷却作用をほとん ど受けていない. したがって，それらの地点は，永 久凍土の発達には適していない地温環境下にあると いえる。また, BTS 值が $-2^{\circ} \mathrm{C}$ 以上を示し, 年平均 地表面温度も $0^{\circ} \mathrm{C}$ を上回っていることから，TE1， TE3 と OK1 には永久凍土が存在しないと判断され る.

南沢北カール内の岩石水河（RG5）上部のリッジ 上に位置する NM1 と NM3 では，冬季に扔ける地表 面温度は明瞭な日変化を伴いながら，ほぼ $0^{\circ} \mathrm{C}$ 以下 で推移した。このことは，NM1 と NM3 は主稜線西 側の風衝側に位置する岩石水河（RG5）上部のリッ ジ上にあるため，冬季季節風によって雪が吹き払わ れてしまい, 寒冷な外気を遮断する程度の積雪深 (約 $80 \mathrm{~cm}$ 以上) とはならないことを示しているので あろう。このように, NM1 と NM3 における地表面 温度は, 冬季においても寒冷な外気の影響を受けや すいことが示唆されたため，BTS 值に基づいた永久 凍土の有無に関する推定をおこなうには適していな い条件下にあるといえよう。そのため，この 2 地点 に打ける永久凍土の有無については, 年平均地表面 温度に基づいた推定をおこなう。

NM1 に扮ける年平均地表面温度は, 2000 年 10 月〜 2001 年 9 月と 2001 年 10 月 2002 年 9 月の值 はともに $0.8^{\circ} \mathrm{C}, 2002$ 年 10 月 2003 年 9 月と 2003 年 10 月〜2004 年 9 月の值はともに $1.3^{\circ} \mathrm{C}$ であり, 観測期間内における NM1の年平均地表面温度は $1^{\circ} \mathrm{C}$ 前後の值を示した。NM3 における 2002 年 10 月〜2003 年 9 月にかけての年平均地表面温度は $1.6^{\circ} \mathrm{C}$ であった.

このように, NM1 と NM3 に扔ける年平均地表面 温度は, 永久凍土の存在を示唆する年平均地表面温 度の值 $\left(0^{\circ} \mathrm{C}\right.$ 以下) をやや上回っていた。一方, NM1 および NM3 と同じ岩石水河（RG5）上に位置 する NM2, NM4，NM5 では，BTS 值が $-3{ }^{\circ} \mathrm{C}$ を下 
回っており，永久凍土存在の可能性が高いといった 結果が得られている。したがって，この岩石水河の 内部には，局所的（パッチ状）に永久凍土が存在し ていることが考えられる.

\section{VI 結 論}

飛騨山脈南部の槍・穂高連峰において, 永久凍土 の有無およびその分布状況を気温および地表面温度 から推定するため, 小型自記温度計を用いた気温・ 地温観測をおこなった。その結果，以下のことが明 らかとなった。

1） 2000 年秋季から 2005 年秋季までの槍・穂高 連峰主稜線上の南岳小屋における年平均気温は $-2.2^{\circ} \mathrm{C} \sim-3.1^{\circ} \mathrm{C}$ 示し, その気温状況は不連続山 岳永久凍土帯に相当することが確実であることが示 された。

2）天狗原カール, 南沢北カール, 大キレットカー ルなどの内部に存在する岩石水河上の複数の地点お よび大キレットカール北向き崖錐斜面下部では, BTS 值が $-2^{\circ} \mathrm{C}$ を下回ったことから，それらの地点 には永久凍土が存在する可能性がある。特に, 大キ レットカール内の岩石水河上の複数の地点に扔いて, 複数年の $\mathrm{BTS}$ 值が $-3^{\circ} \mathrm{C}$ を下回り, 年平均地表面 温度も $0^{\circ} \mathrm{C}$ を回る地点があったことから, それら の地点に抢ける永久凍土存在の可能性は高い.

3）他地点よりも礫径の大きな粗大礫が多く存在 している大キレットカール内の観測地点では, 冬季 に厚い積雪に覆われているにもかかわらず，積雪底 地表面温度が他地点より顕著に低下した所がある. これは, 冬季においても粗大礫の一部が積雪面上に 露出し, その粗大啋の露出部が寒冷な外気によって 冷却されていき，粗大礫を通した冷却作用が冬季に おける積雪底地表面温度の低下に大きく影響して, 永久凍土の形成に有利な地温環境が形成されている ことを示すと考えられる。

4）天狗原カールと大キレットカール内の岩石水河
頂面に明暸な閉塞凹地が存在する地点や, 岩石水河 頂面とその周囲との比高が小さい地点などにおいて は, 多量の積雪に覆われる冬季の地表面温度に顕著 な低下が生じておらず，BTS 值は $-2^{\circ} \mathrm{C}$ を回り， 年平均地表面温度も $0^{\circ} \mathrm{C}$ を回っていたことから， それらの地点には永久凍土は存在しない.

5）冬季の積雪が少ない風衝側に位置する南沢北 カールの岩石水河（RG5）上部のリッジ上における 年平均地表面温度は $1^{\circ} \mathrm{C}$ 前後であり, 永久凍土の存 在を示唆する值 $\left(0^{\circ} \mathrm{C}\right.$ 以下) を上回った。一方，こ の岩石水河上に位置する他の観測地点では, BTS 值 が $-3^{\circ} \mathrm{C}$ を下回り, 永久凍土存在の可能性が高いこ とが示されていることから，この岩石水河の内部に はパッチ状に永久凍土が存在していることが考えら れる。

本研究を進めるにあたり, 南岳小屋の皆様には, 現地 調査の際に便宜をはかっていただいた。当時東京都立大 学 (現首都大学東京) 地理学教室の岩田修二先生（現立 教大学), 塚本すみ子先生 (現 Leibniz Institute for Applied Geosciences）からは, 多くの御助言と励ましを 受けた。東京都立大学地理学教室 (当時), 寒冷地形談 話会の諸氏からは，有益なコメントをいただいた。記し て厚く御礼申し上げます.

本稿の骨子は日本地理学会 2004 年度春季学術大会に 扔いて発表した。

(投稿 2010 年 3 月 18 日)

(受理 2010 年 9 月 11 日)

\section{文 献}

青山雅史 2002a．日本アルプスのカール内に分布する岩塊 堆積地形の成因——岩石水河説に基づく再検討. 地理学 評論 75: 529-543.

青山雅史 $2002 \mathrm{~b}$. 温度状況および形態的特徵に基づく飛騨 山脈槍穂高連峰に扔ける岩石水河の活動状態の評価. 地 学雑誌 111: 583-593.

五百沢智也 1979.『鳥瞰図譜 $=$ 日本アルプス』講談社.

石川守 ·岩崎正吾 · 澤柿教伸 ·平川一臣 · 渡辺悌二 2002. 北海道日高山脈ポロシリ岳周辺に扔ける山岳永久 凍土環境——気温と地表面温度観測からの考察. 地学雑 誌 111: 574-582.

澤田結基・石川 守 2002. 西ヌプカウシヌプリに扔ける 
岩塊斜面の永久凍土環境. 地学雑誌 111：555-563.

式 正英 1975. 岩石水河, 気候段丘の地形的特色と意義. 式 正英編『日本の水期の諸問題』57-71. 古今書院.

高橋伸幸 1999. 飛騨山脈南岳高山帯に抢ける気温・地温 状況. 高橋伸幸編『日本の高山帯に扔ける周水河現象と その環境に関する研究』(平成 $7 \sim 9$ 年度文部省科学研究 費補助金（基盤研究 B）研究成果報告書）96-107. 北海 学園大学工学部.

高橋伸幸 - 曾根敏雄 1988. 北海道中央高地, 大雪山平ヶ 岳南方湿原のパルサ．地理学評論 61A：665-684.

原山智 1990 .『上高地地域の地質』地域地質研究報告 (5 万分の) 1 地質図幅). 地質調査所.

福井幸太郎・岩田修二 2000, 立山, 内蔵助カールでの永 久凍土の発見. 雪水 $62: 23-28$.

福田正巳 · 木下誠一 1974. 大雪山の永久凍土と気候環境. 第四紀研究 12：192-202.

藤井理行 1980. 北半球における山岳永久凍土の分布と環 境条件. 雪水 42：41-52.

藤井理行 - 樋口敬二 1972 . 富士山の永久凍土. 雪水 34 ： 173-186.

Aoki, T. and Hasegawa, H. 2003. Late Quaternary glaciations in the Japanese Alps controlled by sea level changes, monsoon oscillations and topography. Zeitschrift für Geomorphologie Supplementband 130: 195-215.

Aoyama, M. 2005. Rock glaciers in the northern Japanese Alps: Palaeoenvironmental implications since the Late Glacial. Journal of Quaternary Science 20: 471-484

Barsch, D. 1996. Rockglaciers: Indicators for the present and former geoecology in high mountain environments. Berlin: Springer.

Etzelmüller, B., Hoelzle, M., Soldøjrg, Fo., Heggem, E., Isaksen, K., Mittaz, C., Vonder Mühll, D., Ødegard, R. S., Haebrli, W. and Sollid, J. L. 2001. Mapping and modelling the occurrence and distribution of mountain permafrost. Norsk Geografisk Tidsskrift 55: 186-194.

Gądek, B. and Kędzia, S. 2008. Winter ground surface temperature regimes in the zone of sporadic discontinuous permafrost, Tatra mountains (Poland and Slovakia). Permafrost and Periglacial Processes 19: 93-304.

Gómez, A., Palacios, D., Ramos, M., Tanarro, L. M., Schulter, L. and Salvador, F. 2001. Location of permafrost in marginal regions: Corral del Veleta, Sierra Nevada, Spain. Permafrost and Periglacial Processes 12: 93-110.

Haeberli, W. 1973. Die Basis-Temperatur der winter- lichen Schneedecke als möglicher Indikator für die Verbreitung von Permafrost in den Alpen. Zeitschrift für Gletscherkunde und Glazialgeologie 9: 221-227.

Haeberli, W. 1983. Permafrost-glacier relationships in the Swiss Alps-today and in the past. Proceedings of the Fourth International Conference on Permafrost: 415-420.

Haeberli, W. 1985. Creep of mountain permafrost : Internal structure and flow of alpine rock glaciers. Mitteilungen der Versuchsanstalt für Wasserbau, Hydrologie und Glaziologie. No. 77. Zürich: ETH.

Haeberli, W. 1992. Construction, environmental problems and natural hazards in periglacial mountain belts. Permafrost and Periglacial Processes 3: 111-124.

Haeberli, W. and Patzelt, G. 1982. Permafrostkartierung im Gebiet der Hochebenkar blockgletscher, Obergurgl, Oetztaler Alpen. Zeitschrift für Gletscherkunde und Glazialgeologie 18: 127-150.

Haeberli, W., Guodong, C., Gorbunov, A. P. and Harris, S. A. 1993. Mountain permafrost and climate change. Permafrost and Periglacial Processes 4: 165-174.

Harris, C., Haeberli, W., Vonder Mühll, D. and King, L. 2001. Permafrost monitoring in the high mountains of Europe: The PACE project in its global context. Permafrost and Periglacial Processes 12: 3-11.

Harris, S. A. 1981. Climatic relations of permafrost zones in areas of low winter snow-cover. Arctic 34: $64-70$.

Harris, S. A. and Pedersen, D. E. 1998. Thermal regimes beneath coarse blocky material. Permafrost and Periglacial Processes 9: 107-120.

Higuchi, K. and Fujii, Y. 1971. Permafrost at the summit of Mount Fuji, Japan. Nature 230: 521.

Hoelzle, M. 1992. Permafrost occurrence from BTS measurements and climatic parameters in the Eastern Swiss Alps. Permafrost and Periglacial Processes 3: 143-147.

Hoelzle, M., Haeberli, W. and Keller, F. 1993. Application of BTS-measurements for modeling mountain permafrost distribution. Proceedings of the Sixth International Conference on Permafrost: 272-277.

Hoelzle, M., Haeberli, W. and Stocker-Mittaz, C. 2003. Miniature ground temperature data logger measurements 2000-2002 in the Murtèl-Corvatsch area, Eastern Swiss Alps. Proceedings of the Eighth International Conference on Permafrost: 419-424.

Hoelzle, M., Mittaz, C., Etzelmüller, B. and Haeberli, W. 2001. Surface energy fluxes and distribution models 
relating to permafrost in European Mountain Permafrost areas: An overview of current developments. Permafrost and Periglacial Processes 12: $53-68$.

Ikeda, A. 2006. Combination of conventional geophysical methods for sounding the composition of rock glaciers in the Swiss Alps. Permafrost and Periglacial Processes 17: 35-48.

Ikeda, A. and Matsuoka, N. 2002. Degradation of Talusderived rock glaciers in the Upper Engadin, Swiss Alps. Permafrost and Periglacial Processes 13: 145161.

Imhof, M., Pierrehumbert, G., Haeberli, W. and Kienholz, H. 2000. Permafrost investigation in the Schilthorn Massif, Bernese Alps, Switzerland. Permafrost and Periglacial Processes 7: 267-280.

Ishikawa, M. 2003. Thermal regime at the snow-ground interface and their implications for permafrost investigation. Geomorphology 52: 105-120.

Ishikawa, M. and Hirakawa, K. 2000. Mountain permafrost distribution based on BTS measurements and DC resistivity soundings in the Daisetsu mountains, Hokkaido, Japan. Permafrost and Periglacial Processes 11: 109-123.

Ishikawa, M., Fukui, K., Aoyama, M., Ikeda, A., Sawada, Y. and Matsuoka, N. 2003. Mountain permafrost in Japan: distribution, landforms and thermal regimes. Zeitschrift für Geomorphologie Supplementband 130: 99-116.

Ito, M. and Vorndran, G. 1983. Glacial geomorphology and snow-lines of younger Quaternary around the Yari-Hotaka Mountain Range, Northern Alps, Central Japan. Polarforschung 53: 75-89.

Janke, J. R. 2005. The occurrence of alpine permafrost in the Front Range of Colorado. Geomorphology 67:
375-389

Juliussen, H. and Humlum, O. 2008. Thermal regime of openwork block fields on the mountains Elgåhogna and Sølen, Central-eastern Norway. Permafrost and Periglacial Processes 19: 1-18.

King, L. 1983. High mountain permafrost in Scandinavia. Proceedings of the Fourth International Conference on Permafrost: 612-617.

Matsuoka, N. and Ikeda, A. 1998. Some observations regarding mountain permafrost in the Japanese Alps. Annual Report of the Institute of Geoscience, the University of Tsukuba 24: 19-25.

Matsuoka, N. and Ikeda, A. 2003. Intensive cooling through an open-work blocky layer: Ground temperature monitoring in the Swiss Alps. Annual Report of the Institute of Geoscience, the University of Tsukuba 29: 21-25.

Sawada, Y., Ishikawa, M. and Ono, Y. 2003. Termal regime of sporadic permafrost in a blockslope on Mt. Nishi-Nupukaushinupuri, Hokkaido Island, Northern Japan. Geomorphology 52: 121-130.

Shiki, M. 1969. Recent alpine geomorphological studies in Japan. Ochanomizu University Studies in Arts and Culture 22: 69-81.

Sone, T. 1992. Permafrost environment of the Daisetsu Mountains. Permafrost and Periglacial Processes 3: 235-240

Vonder Mühll, D., Hauck, C. and Gubler, H. 2002. Mapping of mountain permafrost using geophysical methods. Progress in Physical Geography 26: 640657

Wahrhaftig, C. and Cox, A. 1959. Rock glaciers in the Alaska Range. Bulletin of the Geological Society of America 70: 383-436 
Geographical Review of Japan Series A 84-1 44-60 2011

\title{
Mountain Permafrost Distribution in the Yari-Hotaka Mountains, Northern Japanese Alps: Air and Ground Temperature Monitoring Using Miniature Temperature Data Loggers
}

\author{
AOYAMA Masafumi (Japan Map Center)
}

Air and ground temperatures were monitored on and around blocky deposits such as rock glaciers and talus slopes in the alpine zone of the Yari-Hotaka Mountains, northern Japanese Alps, using miniature temperature data loggers. The results of air temperature monitoring indicated that the mean annual air temperature in the summit area of the Yari-Hotaka Mountains was about $-2.5^{\circ} \mathrm{C}$, and this area belong to the discontinuous permafrost area.

The results of ground surface temperature at leeward sites (Tenguppara cirque and Oh-kiretto cirque) showed that a sufficiently thick snow cover insulates the ground surface from short-term variations in atmospheric conditions during the winter. At some of these sites, the bottom temperatures of snow cover (BTS) in late winter were less than $-3^{\circ} \mathrm{C}$, and mean annual ground surface temperatures (MAST) were less than $0^{\circ} \mathrm{C}$. These results suggest that mountain permafrost can be present in some blocky deposits. BTS values at significantly large boulder site were distinctly colder than those at other sites. This intensive cooling of the ground surface may be caused by conduction through surface boulders protruding into and through the snow cover.

At some wind-blown sites located on a rock glacier in the northern Minamisawa cirque, ground surface temperatures were influenced by atmospheric variations throughout the whole winter, and MAST was close to $1^{\circ} \mathrm{C}$. Ground surface temperature evolution on the furrows of this rock glacier do not undergo short-term fluctuations during the winter, and BTS in late winter at these sites was less than $-3^{\circ} \mathrm{C}$. These results suggest the occurrence of patchy permafrost in this rock glacier.

Key words: mountain permafrost, ground surface temperature, bottom temperature of the winter snow cover (BTS), blocky deposits, Yari-Hotaka Mountains 